\title{
$\mathrm{MgSO}_{4}$ と $\mathrm{NaHCO}_{3}$ の混合水溶液による 各種アルミニウム合金の化成処理
}

磯部保明*, 田中慎一*, 保田昌樹**, 日根文男**

$*$ 名古屋工業大学大学院, ** 名古屋工業大学

\section{Chemical Conversion Treatment of Aluminum Alloys with the Mixed Solution of $\mathrm{MgSO}_{4}$ and $\mathrm{NaHCO}_{3}$}

\author{
Yasuaki Isobe*, Shin-ichi Tanaka*, Masaki Yasuda** and Fumio Hine** \\ * Graduate School, Nagoya Institute of Technology \\ ** Nagoya Institute of Technology
}

\begin{abstract}
The effects of alloy elements in aluminum alloys on the corrosion preventive layer prepared by the chemical conversion with dilute solutions containing $\mathrm{MgSO}_{4}$ and $\mathrm{NaHCO}_{3}$ were investigated. Both A 5052 and A 7072 were resistant to a dilute $\mathrm{NaCl}$ solution containing cupric ions, similar to pure aluminum $(99.99 \% \mathrm{Al})$, when they were pretreated to obtain the protective film. The alloy elements, $\mathrm{Mg}$ in A 5052 and $\mathrm{Zn}$ in A 7072, existed as the solid solution. On the other hand, $\mathrm{Cu}$ in $\mathrm{A} 2017$ and $\mathrm{Mn}$ in A 3003, may form the intermetallic compounds such as $\mathrm{CuAl}_{2}$ and $(\mathrm{Fe}, \mathrm{Mn}) \mathrm{Al}_{8}$, and $\mathrm{Si}$ in BA 4045 forms an eutectic mixture. The films on A 2017, A 3003, and BA 4045 were poor, and hence the resistivity to pitting was insufficient.
\end{abstract}

Key words: aluminum alloy, alloy element, pitting corrosion, chemical conversion treatment

\section{1. 緒言}

アルミニウムおよびアルミニウム合金の防食を目的と して，既に種々の化成処理法が考察され，実施されてい るけれども1) 11)，いずれの防食処理材の耐食性も $\mathrm{Cl}^{-}$ イオンと $\mathrm{Cu}^{2+}$ イオンを含む孔食発生加速試験溶液中で はなお不充分である。

しかし，天然海水または人工海水中でアルミニウムを 煮沸処理すると耐食性に優れた乳白色の化成皮膜が容易

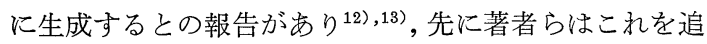
試し, 検討した ${ }^{14)}$ 。その結果, 比較的高純度のアルミニ ウム（A 1050）を硫酸マグネシウムと重炭酸ナトリウム の混合水溶液中で者沸処理すると, アルミニウムとマグ ネシウム新よび硫酸根を含む化成処理皮膜 $(\mathrm{Mg}$ 処理皮 膜）が表面に生成し， $\mathrm{Cl}^{-}$イオンと $\mathrm{Cu}^{2+}$ イオンを含む 孔食加速試験溶液中でも優れた耐孔食性を示した。

本研究では各種アルミニウム合金の $\mathrm{Mg}$ 処理皮膜生

*,** $\bar{T} 466$ 名古屋市昭和区御器所町 (Gokiso-cho, Showa-ku, Nagoya 466, Japan)
成に执ける合金成分の影響と， $\mathrm{Cu}^{2+}$ イオンを含さ中性 の $\mathrm{NaCl}$ 水溶液中に打汀る耐孔食性の差異について考察 した。

\section{2. 実験方法}

供試したアルミニウム括よびアルミニウム合金は純度 99.99\% 以上の高純度アルミニウム (JIS 規格にないが便 宜上, A 1099 と記す), A 1050 (純度 99.5\%), A 2017 ( $\mathrm{Cu}$ 含有), A 3003 (Mn 含有), BA 4045 ( $\mathrm{Si}$ 含有), A 5052 $(\mathrm{Mg}$ 含有), および A 7072 ( $\mathrm{Zn}$ 含有) の $\mathrm{O}$ 材 (板厚 1 $\mathrm{mm})$ で, その化学成分を Table 1 に示す。供試材を $5 \%$ 水酸化ナトリウム水溶液でェッチング $\left(60^{\circ} \mathrm{C}, 30\right.$ 秒) 乙, 水洗, $30 \%$ 硝酸水溶液でデスマット(室温, 1 分間) 後, 水洗し, 前洗浄 ${ }^{15)}$ した。

温度約 $95^{\circ} \mathrm{C}$ の $\mathrm{Mg}$ 処理液 (組成：0.05 $\mathrm{M} \mathrm{MgSO}_{4}+$ $0.005 \mathrm{M} \mathrm{NaHCO}$ ) に, 前洗浄した供試材を 30 分浸せ きし, $\mathrm{Mg}$ 処理した ${ }^{14)}$ 。供試材の表面積当たりの比液量 を $5 \mathrm{cc} / \mathrm{cm}^{2}$ とした。 
Table 1 Chemical composition of the aluminum alloys examined $(\%)$.

\begin{tabular}{c|ccccccccr}
\hline \hline Alloy & $\mathrm{Si}$ & $\mathrm{Fe}$ & $\mathrm{Cu}$ & $\mathrm{Mn}$ & $\mathrm{Mg}$ & $\mathrm{Cr}$ & $\mathrm{Zn}$ & $\mathrm{Ti}$ & $\mathrm{Al}$ \\
\hline A 1099 & 0.001 & 0.001 & 0.005 & - & - & - & - & - & bal. \\
\hline A 1050 & 0.08 & 0.31 & 0.01 & - & - & - & - & 0.02 & bal. \\
\hline A 2017 & 0.68 & 0.40 & 4.02 & 0.61 & 0.57 & 0.01 & 0.08 & 0.03 & bal. \\
\hline A 3003 & 0.24 & 0.68 & 0.15 & 1.15 & 0.011 & 0.002 & 0.005 & 0.016 & bal. \\
\hline BA 4045 & 9.82 & 0.39 & 0.04 & 0.01 & 0.02 & - & 0.02 & 0.02 & bal. \\
\hline A 5052 & 0.08 & 0.19 & 0.02 & 0.05 & 2.6 & 0.21 & 0.01 & - & bal. \\
\hline A 7072 & 0.019 & 0.30 & 0.003 & 0.005 & - & - & 1.15 & - & bal. \\
\hline
\end{tabular}

$0.01 \mathrm{M} \mathrm{NaCl}$ 水溶液 $\left(\mathrm{pH}=7.0 \pm 0.5,40^{\circ} \mathrm{C}\right.$. 以下, 孔 食試験溶液と言う) に空気を通気しつつ, 試験片 $(10$ $\left.\mathrm{cm}^{2}\right)$ を 336 時間浸せきして孔食試験を行った。試験片 を浸せきしてから約 2，100，および 200 時間後に，pH が変化しないように注意しながら $\mathrm{Cu}^{2+}$ イオン $\left(\mathrm{CuSO}_{4}\right.$. $5 \mathrm{H}_{2} \mathrm{O}$ を使用) を $10 \mathrm{ppm}$ ずつ添加した。試験中の自然 電位の経時変化を銀/塩化銀電極基準 (以下, 本文では V vs. $\mathrm{Ag} / \mathrm{AgCl}$ を $\mathrm{V}$ と略記する) で測定した。試験後, 試 験片表面に生成した腐食生成物を $50 \%$ 硝酸水溶液で除 去し，光学顕微鏡による焦点合わせで孔食深さを測定し た。

あらかじめ高純度窒素ガスを通じて充分脱酸素した孔 食試験溶液中にて電位走査法 (電位走查速度 $20 \mathrm{mV} / \mathrm{min}$ ) で供試材を陽分極し, 電流密度が急増する点を孔食電位 とした。また，空気を吹き込んだ孔食試験溶液中で陰分 極測定し, $\mathrm{Mg}$ 処理皮膜の酸素還元反応に対する抑制効 果を調べた。溶液の IR 損はカレントインタラプタ法で 補正した。

走査型電子顕微鏡 (SEM) で試料の表面観察を行い, $\mathrm{X}$ 線マイクロアナライザー (EPMA) を用いて Mg 処理 皮膜表面の $\mathrm{Mg}$ 濃度を測定した。

\section{3. 結果と考察}

\section{$3.1 \mathrm{Mg}$ 処理による皮膜生成}

$\mathrm{Mg}$ 処理溶液に各種アルミニウム合金を浸せさした時 の自然電位の経時変化を Fig. 1 に示す。電位変化を観測 しやすくするため, 液温を $80^{\circ} \mathrm{C}$ とた。通常, 沸点に 近い高温で $\mathrm{Mg}$ 処理すると処理時間が短く, また正常な $\mathrm{Mg}$ 処理皮膜が生成すると自然電位は $-1.4 \mathrm{~V}$ 以下にな ることがわかっている ${ }^{14)}$ 。正常な $\mathrm{Mg}$ 処理皮膜が生成す る A 1099, A 1050, A 5052, および A 7072 では自然電 位は約 $-1.5 \mathrm{~V}$ と卑な電位領域に停滞するのに対し, $\mathrm{A}$ 2017，A 3003，および BA 4045 では皮膜が充分生成しな いために電位が $-1.0 \sim-1.1 \mathrm{~V}$ と比較的貴な領域にと どまった。

$\mathrm{Mg}$ 処理皮膜は $\mathrm{HCO}_{3}$-イオンの作用により溶解した $\mathrm{AlO}_{2}$-イオンが $\mathrm{Mg}^{2+}$ イオンや $\mathrm{SO}_{4}{ }^{2-}$ イオンと共にア ルミニウム表面に堆積する複合塩基性塩であると考えら

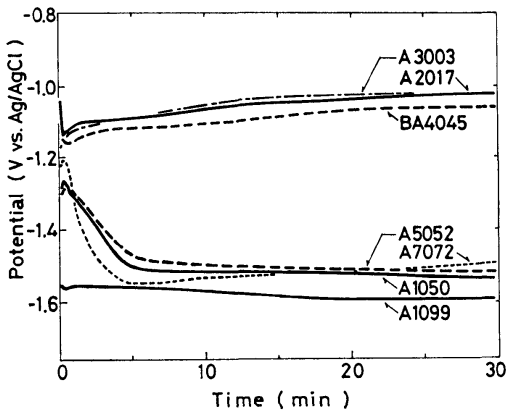

Fig. 1 Time variation in the static potential of the aluminum alloys during the conversion treatment at $80^{\circ} \mathrm{C}$.

れる。正常な $\mathrm{Mg}$ 処理皮膜は厚さが $10 \mu \mathrm{m}$ 以下であり $\mathrm{X}$ 線的に非晶質構造を示すが，電気絶縁性が高い ${ }^{14)}$ 。 $\mathrm{Mg}$ 処理したアルミニウム合金の表面状態を Fig. 2 に 示す。A 1099 は極めて均一な皮膜が生成していた。A 1050, A 5052, 抢よび A 7072 上の皮膜は塊状に生成した クラスターが点在するもののほぼ均一であるから, Mg

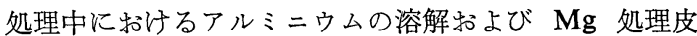
膜の析出反応が試料表面全体にわたって比較的均一に進 行したものと考觉られる。一方，A 2017，A 3003，扎よび BA 4045 の表面には多数のクラスターが見られ，クラス タ一の存在しない部分の皮膜は薄い。後述するように, これらのアルミニウム合金 (A 2017，A 3003，BA 4045) では $\mathrm{CuAl}_{2}$ や $(\mathrm{Fe}, \mathrm{Mn}) \mathrm{Al}_{6}$ などの金属間化合物や晶出 ケイ素が影響するために $\mathrm{Mg}$ 処理中のアルミニウムの 溶解反応が不均一かつ不充分であり，正常な $\mathrm{Mg}$ 処理 皮膜が生成しにくい。

Table $2 に M g$ 処理前後のアルミニウム合金の重量減 と, EPMA で定量分析した Mg 処理皮膜の均一皮膜部 分の $\mathrm{Mg}$ 量を示す。試料を $30 \%$ 硝酸に浸せき (室温, 10 秒間) 後, $5 \%$ リン酸 $-2 \%$ クロム酸溶液に浸せき $\left(80^{\circ} \mathrm{C}\right.$, 20 分 $)^{13), 16)}$ して $\mathrm{Mg}$ 処理皮膜を除去した。A 1099, A 1050, A 5052, および A 7072 ではアルミニウム母材の溶 解量が多く, また $\mathrm{Mg}$ 量が $2.5 \%$ 以上あり, 充分に皮膜 が生成していることを示している。合金成分として $\mathrm{Mg}$ を含むA 5052 は母材の影響を受け，Mg の分析值が高 くなっている。一方, A 2017, A 3003, および BA 4045 は $\mathrm{Mg}$ 処理中のアルミニウム母材の溶解量が少なく, し かも不均一であるから, 均一皮膜部分の $\mathrm{Mg}$ 量が 0.5 $1.3 \%$ と低く, 膜厚が薄い。

$\mathrm{Mg}$ 処理皮膜を除去した試料の表面状態を Fig. 3 に 示す。 $\mathrm{A} 1099$ は $\mathrm{Mg}$ 処理により母材が均一に溶解する。 A 1050, A 5052, および A 7072 も小孔が点在するものの 母材はほぼ均一に溶解している。この小孔は母材の溶解 と共に金属間化合物（後述）が脱落してできたものと思 

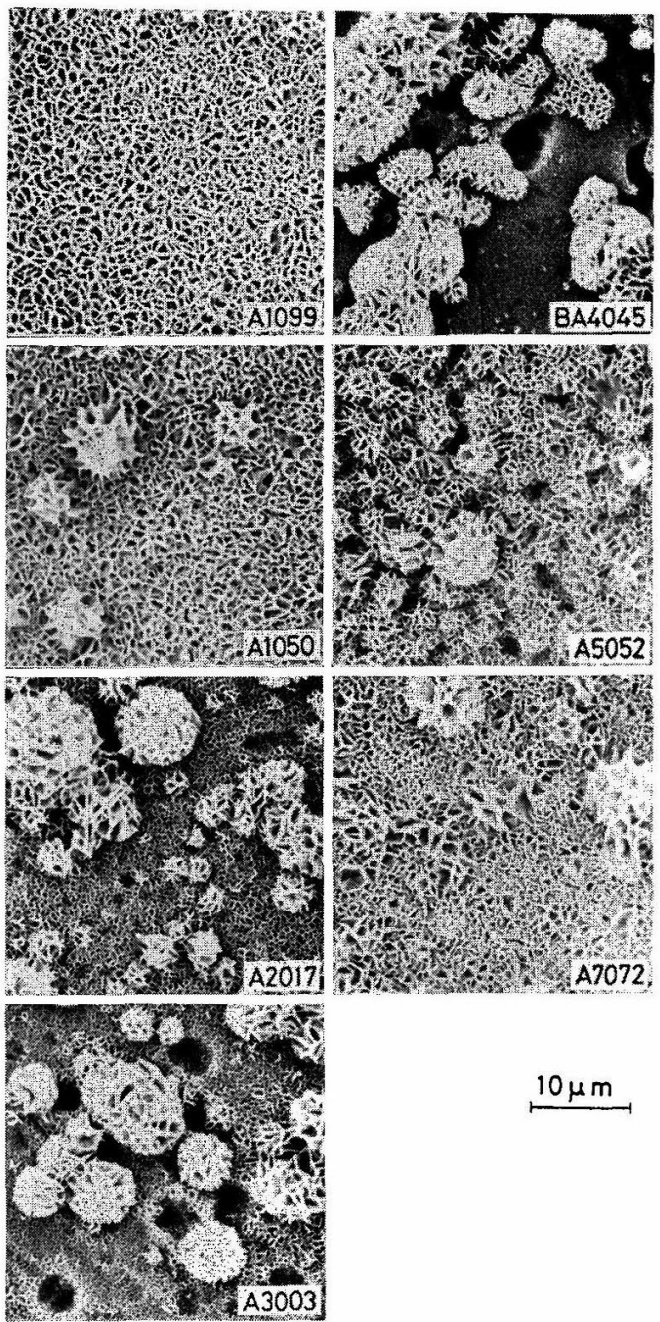

Fig. 2 Electron micrographs of the film on various alloys.

Table 2 Weight loss caused by the conversion treatment and the $\mathrm{Mg}$ content on the surface evaluated by the EPMA analy$\operatorname{sis}(\mathrm{K} \alpha)$.

\begin{tabular}{c|cccccccc}
\hline Alloy & A1099 & A1050 & A2017 & A3003 & BA4045 & A5052 & A7072 \\
\hline $\begin{array}{c}\text { Weight Loss } \\
\left(\mu \mathrm{g} / \mathrm{cm}^{2}\right)\end{array}$ & 94 & 82 & 44 & 56 & 19 & 96 & 88 \\
\hline $\begin{array}{c}\text { Xray Intensity } \\
\text { of Mg }(\%)\end{array}$ & 2.9 & 2.5 & 1.3 & 1.3 & 0.5 & 3.5 & 2.5 \\
\hline
\end{tabular}

われる。一方, 正常な $\mathrm{Mg}$ 処理皮膜が生成しにくい $\mathrm{A}$ 2017, A 3003, および BA 4045 では化合物相が溶解せず に残り，その周辺のアルミニウム下地が局所的に溶解し ていた。これらの化合物相を EPMA 分析した結果, A 2017 では $\mathrm{Cu}, \mathrm{Fe}-\mathrm{Mn}$, および Si が, A 3003 では FeMn が，交た BA 4045 では Si がそれぞれ検出された。 このような元素分析結果と文献を参照した結果，A 2017
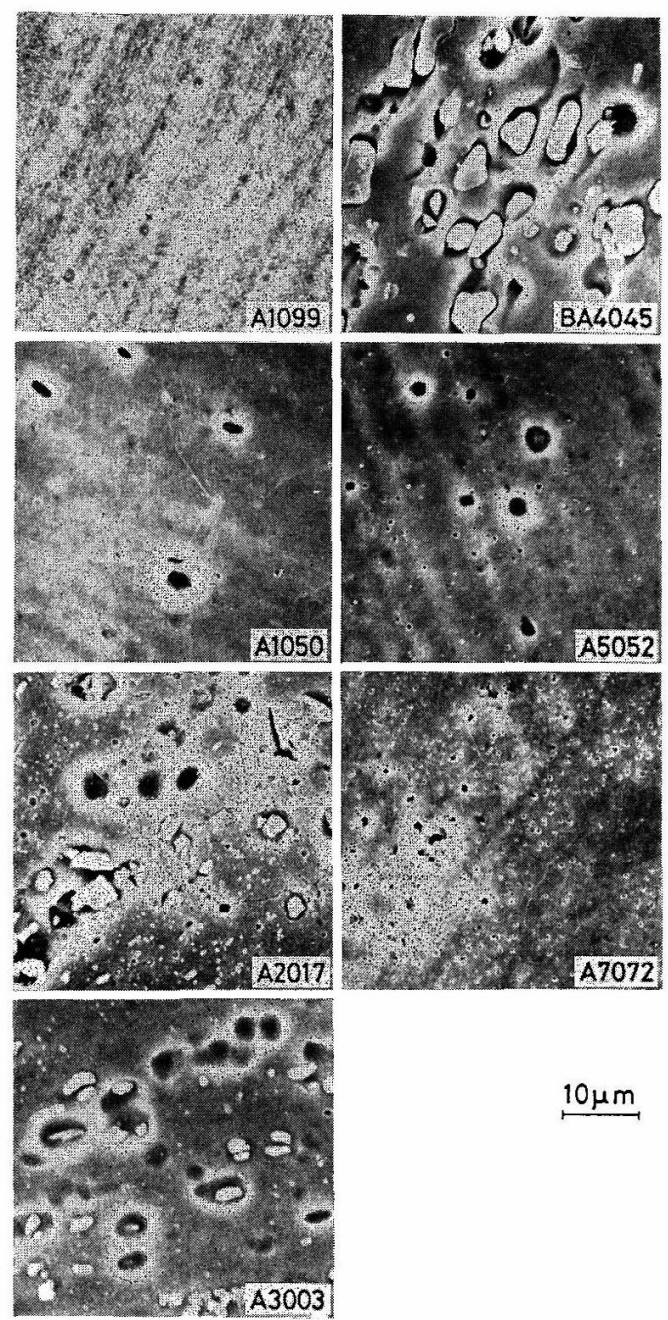

$10 \mu \mathrm{m}$

Fig. 3 Electron micrographs of the surface of aluminum alloys after removing the conversion treatment films.

では $\mathrm{CuAl}_{2}{ }^{17)},(\mathrm{Fe}, \mathrm{Mn}) \mathrm{Al}_{6}$ および $\mathrm{Si}, \mathrm{A} 3003$ では $(\mathrm{Fe}, \mathrm{Mn}) \mathrm{Al}_{8}{ }^{18)}$,19)，また BA 4045 では $\mathrm{Si}^{20)}$ が金属間化 合物および晶出ケイ素として存在していると考㝋られ る。アルミニウムに比べてこれら金属間化合物および晶 出ケイ素は自然電位が高いので21), $\mathrm{Mg}$ 处理中のアルミ ニウム下地の溶解反応が金属間化合物および唱山ヶイ素 周辺に限られやすい。そのため, 金属間化合物蚛よび晶 出ケイ素周辺には $\mathrm{Mg}$ 処理皮膜が塊状に堆積するもの の，その他の部分では均一な皮膜が生成しにくい。A 1050 には金属間化合物として $\mathrm{FeAl}_{3}$ と $\alpha(\mathrm{Fe}, \mathrm{Si})$ が存 在するが20)，微量なために $\mathrm{Mg}$ 処理には悪影響していな い。またA 5052 の合金成分である Mg はほとんどアル ミニウムに固溶して特り20),22)，また仮に金属間化合物 $\mathrm{Mg}_{2} \mathrm{Al}_{3}$ として存在したとしても， $\mathrm{Mg}_{2} \mathrm{Al}_{3}$ の自然電位は アルミニウムに比べて低く ${ }^{21)}, \mathrm{Mg}$ 処理中に溶解するた 
め, 正常な $\mathrm{Mg}$ 処理皮膜が生成する。同様に A 7072 に 含まれる Zn はアルミニウムと完全に固溶する20)ため, $M g$ 処理に影響していない。

アルミニウムに比べ電気化学的に貴な金属間化合物お よび晶出ヶイ素がアルミニウム中に存在すると $\mathrm{Mg}$ 処 理中のアルミニウムの溶解反応が局所的になり, 生成し た皮膜は不均一になる。換言すれば $\mathrm{Mg}$ 処理皮膜が生成 する条件として合金成分がアルミニウムと固溶している ことが必要であろう。

\section{$3.2 \mathrm{Mg}$ 処理材の耐孔食性}

脱酸素した孔食試験溶液中で測定した $\mathrm{Mg}$ 処理材お よび末処理材の陽分極曲線を Fig. 4 に示す。未処理材に 比べて $\mathrm{Mg}$ 処理した A 1099, A 1050, およよ゙ A 5052 の 孔食電位は上昇したが, A 2017, A 3003，㧊よびBA 4045 では $\mathrm{Mg}$ 処理皮膜が不完全であるため孔食電位は注と んど変化していない。A 7072 は比較的低い電位で電流 が流れるがこれはアルミニウムに固溶した $\mathrm{Zn}$ が選択 的に溶解するためであうう。

通気した孔食試験溶液に $\mathrm{Mg}$ 処理したアルミニウム 合金を浸せさして耐孔食性を調べた。浸せき開始 2 時間 後に $\mathrm{Cu}^{2+}$ イオンを $10 \mathrm{ppm}$ 添加し, 孔食発生を加速 ${ }^{23)}$ した場合の自然電位の経時変化の一例を Fig. 5 亿示す。 A 1099, A 1050, 㧊よび A 5052 は $\mathrm{Cu}^{2+}$ イオン添加後
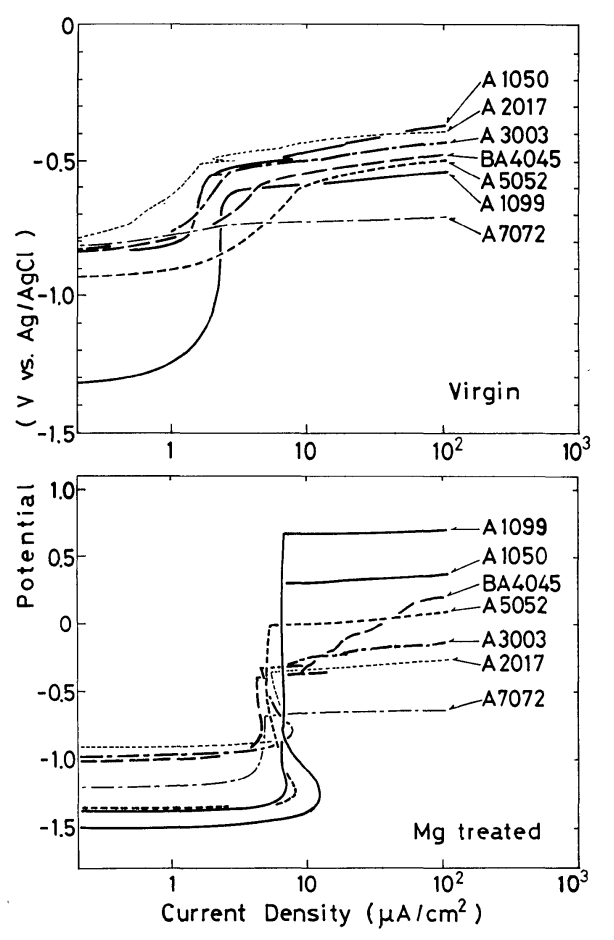

Fig. 4 Anodic polarization curves in deaerated $0.01 \mathrm{M} \mathrm{NaCl}$ solution $\left(\mathrm{pH}=7.2\right.$, at $\left.40^{\circ} \mathrm{C}\right)$. Potential sweep rate $=20 \mathrm{mV} / \mathrm{min}$.

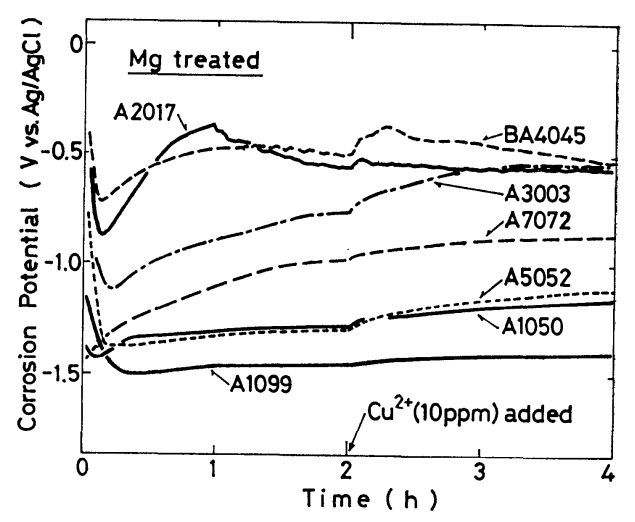

Fig. 5 Time variation in the corrosion potential of the treated alloys in aerated $0.01 \mathrm{M}$ $\mathrm{NaCl}$ solution $\left(\mathrm{pH}=7.0 \pm 0.5\right.$, at $\left.40^{\circ} \mathrm{C}\right)$ before and after the addition of $\mathrm{Cu}^{2+}$ (10 ppm).

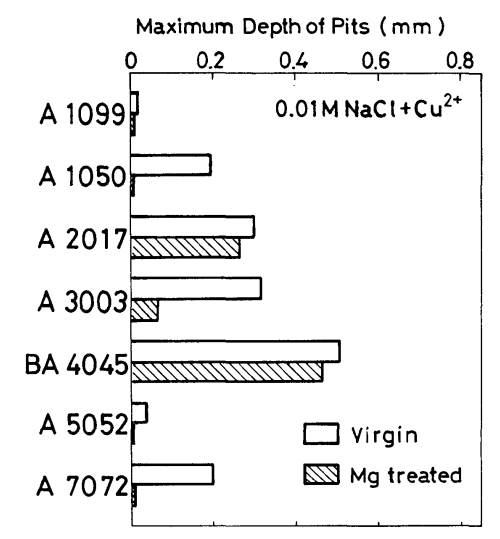

Fig. 6 Maximum depth of the pits generated by the immersion corrosion test with aerated solution $\left(\mathrm{pH}=7.0 \pm 0.5\right.$, at $\left.40^{\circ} \mathrm{C}\right)$ for 336 hours.

も自然電位が低く維持されるために耐孔食性が良好であ る。これに対して A 2017 は浸せき開始後約 1 時間で自 然電位が上昇し，その過程で $\mathrm{Mg}$ 処理皮膜が脱落した。 A 3003 や BA 4045 も同様の傾向を示した。

$\mathrm{Cu}^{2+}$ イオンを含む孔食試験溶液中に 336 時間浸せき した $\mathrm{Mg}$ 処理材抢よび未処理材の最大孔食深さを Fig. 6、纤示す。 $M g$ 処理すると，A 1099，A 1050，A 5052，特 よびA 7072 は優孔た耐食性を示したが, A 3003 はやや 耐孔食性に改善が認められたものの, A 2017 とBA 4045 は $\mathrm{Mg}$ 処理の効果がほとんどなかった。A 1099 は未処 理材でも優れた耐孔食性を示すが，これは高純度アルミ ニウム表面に生成する欠陥のない水和酸化物皮膜が酸素 還元反応に対して不活性なためである(後述)。また $\mathrm{Mg}$ を含む A 5052 の未処理材ももともと自然電位が低い22) ために耐孔食性が良好と考光られる。 


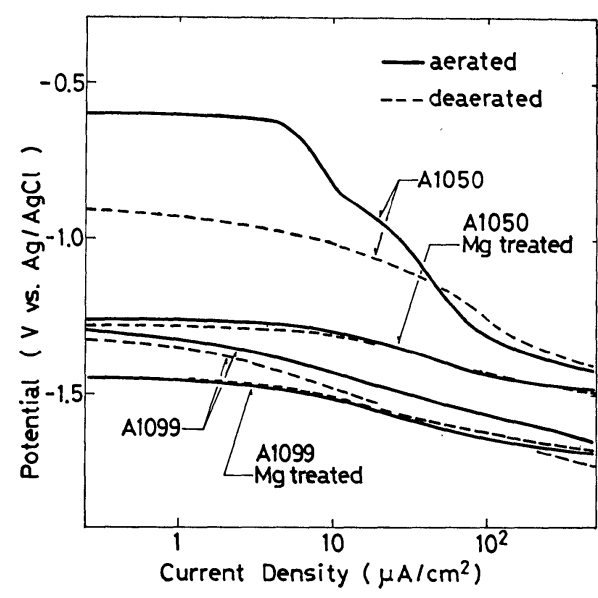

Fig. 7 Cathodic polarization curves in aerated and deaerated $0.01 \mathrm{M} \mathrm{NaCl}$ solutions $\left(\mathrm{pH}=7.2\right.$, at $\left.40^{\circ} \mathrm{C}\right)$. Potential sweep rate $=20 \mathrm{mV} / \mathrm{min}$.

アルミニウム合金の孔食発生反応に拈ける陰極反応は 溶存酸素の還元が主体である24)。Fig. 7 亿通気した孔食 試験溶液中で測定した A 1099 および A 1050 の Mg 処 理材と未処理材の陰分極曲線を示す。参考のために充分 脱酸素した溶液中に括沙る陰分極曲線も併記した。未処 理の A 1099 では溶存酸素の還元電流が認められないの で, アルミニウムの水和酸化物皮膜は酸素還元反応に対 して不活性であると考光られ，A1099 の未処理材が耐 孔食性汇優孔ている証左となっている (Fig. 6)。一方， A 1050 (未処理材) についてはわずかながら酸素拡散限 界電流が認められるので, A 1050 に存在する微量の $\mathrm{FeAl}_{3}$ や $\alpha(\mathrm{Fe}, \mathrm{Si})$ などの金属間化合物の表面で酸素還 元反応が起こっていると考光られる25)。しかし $\mathrm{Mg}$ 処理 した A 1050 では酸素還元反応が抑えられるので, $\mathrm{Mg}$ 処理皮膜が酸素拡散障壁の作用をしていることがわか る。図示していないが，金属間化合物を含むアルミニウ ム合金 (未処理材) はすべて明膫な酸素拡散限界電流を 観測することができる。

アルミニウム合金の耐孔食性を改善する $\mathrm{Mg}$ 処理法 は比較的高純度のアルミニウムや, 合金成分がアルミニ ウムと固溶する合金 (A 1050, A 5052, A 7072) に対して 有効である。正常な $\mathrm{Mg}$ 処理皮膜は自然電位を低下さ せ，かつ溶存酸素の還元反応に対する障壁として作用す る。 $\mathrm{Mg}$ 処理皮膜が不完全に生成する合金 (A 2017, A 3003, BA 4045) では孔食試験中に $\mathrm{Mg}$ 処理皮膜が脱落 乙，電気化学的に貴な金属間化合物掞よび晶出ケイ素が 露出するとその表面で溶存酸素の還元が進み, 孔食が発 生する。

\section{4. 結論}

各種アルミニウム合金の $\mathrm{Mg}$ 処理を検討し, 次の結論 を得た。

(1) 合金成分がアルミニウムと固溶する A 5052 (Mg 含有) と A 7072 ( $\mathrm{Zn}$ 含有) は, A 1099 (99.99\% $\mathrm{Al})$ A $1050(99.5 \% \mathrm{Al})$ と同様に正常な $\mathrm{Mg}$ 処理皮 膜が生成し, $\mathrm{Cu}^{2+}$ イオンを含む中性の $\mathrm{NaCl}$ 水溶液中 に抢ける酎孔食性が向上した。

(2) $\mathrm{CuAl}_{2},(\mathrm{Fe}, \mathrm{Mn}) \mathrm{Al}_{6}, \mathrm{Si}$ などの金属間化合物や 晶出ケイ素が存在する A 2017 (Cu 含有), A 3003 (Mn 含有)，および BA 4045 ( $\mathrm{Si}$ 含有) は $\mathrm{Mg}$ 処理皮膜が不 均一かつ不充分に生成するため, 耐孔食性は注とんど改 善しない。

\section{謝辞}

研究費の一部は文部省科学研究費補助金一般研究 C (課題番号 63550602) による。

実験に協力した卒業研究学生 伊藤正昭, 近藤万紀子, 吉田 哲の諸君に感謝する。

(Received September 12, 1988)

$$
\text { 文献 }
$$

1）前田寿弘：金属表面技術，15, 98 (1964).

2) 馬場宣良：軽金属, 34, 205 (1984).

3）石井 透：“アルミニウム技術便覧,”p. 1285, 軽 金属出版 (1985).

4）中山孝廉: “アルミニウムの表面処理, ” p. 225, 日 刊工業新聞社 (1969).

5) 岡部泰二郎, 目黑 明：金属表面技術， 15, 39 (1964).

6) D. G. Altenpohl: Corrosion, 18, 143 t (1962).

7) W. Vedder \& D. A. Vermilyea: Trans. Faraday Soc., 66, 561 (1969).

8) B. R. Baker \& J. D. Balser: Aluminium, 52, 197 (1976).

9) R. S. Alwitt: J. Electrochem. Soc., 121, 1322 (1974).

10）糸井康彦，内山郁夫，佐藤栄一：金属表面技術, 29, 68 (1978).

11) 山田啓之, 岡本常義：軽金属, 21, 597 (1971).

12) 内山利光, 阿部 隆：軽金属, 32, 202 (1982).

13）内山利光, 長谷川 実, 松本裕志：金属表面技術, 37, 178 (1986).

14）磯部保明，保田昌樹，日根文男：防食技術， 37, 553 (1988).

15）軽金属学会：研究部会報告書, No. 15 アルミニ ウム特よびアルミニウム合金の電気化学的分極測 定, p. 7 (1985).

16) B. W. Samuels, K. Sotoudeh, \& R. T. Foley: Corrosion, 37, 92 (1981).

17) J. R. Galvele \& S. M. De De Micheli: Corrosion Science, 10, 795 (1970).

18) M. Zamin: Corrosion, 37, 627 (1981). 
19）福塚敏夫, 下郡一利, 藤原和雄：防食技術, 28 , 323 (1979).

20) F. King: "Aluminium and Its Alloys", pp. 90129, Ellis Horwood Ltd. (1987).

21) Kent R. V. Horn: "Aluminum”, Vol. 1, p 212 ,
ASM (1971).

22) 内山郁夫, 佐藤栄一：防食技術, 25,725 (1976).

23）当摩 建, 竹内 庸: 軽金属, 33, 457 (1983).

24）伊藤伍郎：軽金属, 31, 683 (1981).

25）世利修美, 田頭孝介：防食技術, 37, 273 (1988). 